TAPROBANICA, ISSN 1800-427X. April, 2010. Vol. 02, No. 01: pp. 25-29, pl. 1.

(C) Taprobanica Nature Conservation Society, 146, Kendalanda, Homagama, Sri Lanka.

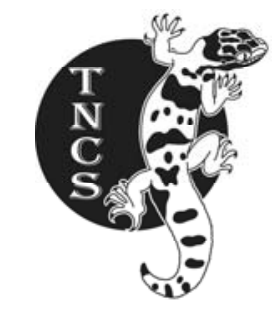

\title{
ADDRESSING THE WALLACEAN SHORTFALL: AN UPDATED CHECKLIST OF ICTHYOFAUNA OF CHEMBARAMPAKKAM TANK
}

\section{J. D. Marcus Knight}

Flat 'L', Sri Balaji Apartments, $7^{\text {th }}$ Main Road, Dhandeeswaram, Velachery, Chennai- 600042.

E-mail: jdmarcusknight@yahoo.co.in

\begin{abstract}
Fish fauna of Chennai has been systematically surveyed for the past 100 years. Subsequent surveys have not been as comprehensive as the first study. As a result premature conclusions about species extinctions and species displacement by introduced species have emerged in publications from time to time. In this paper, I present a comprehensive survey of Chembarampakkam tank, one of the freshwater tanks in Chennai which has been surveyed for the past 100 years. The results highlight the significance of Wallacean shortfall.
\end{abstract}

Key words: Diversity, Freshwater fish, Chembarampakkam, Chennai, Madras, Non-native

\section{Introduction}

Conservation efforts are often challenged by the Wallacean Shortfall. Wallacean Shortfall concerns the adequacy of knowledge of species distribution at different geographical scales. The deficiency in distribution data is not only a common problem in poorly studied organisms but also for well studied organisms like mammals and vascular plants, which sometimes emerge as an embarrassment to the scientific community (Kozlowski, 2008).

Data on the distribution of freshwater fish in India is relatively more complete than that of other lower vertebrates. However when specific localities are in focus the Wallacean Shortfall tends to glare at the investigator. Checklists when updated, are the best tools that can be used to deal with the Wallacean Shortfall. Here in this paper, I describe how updated checklists can add to the knowledge of species distribution. I have chosen the Chembarampakkam tank for the case study presented in this paper. Chembarampakkam tank is a manmade reservoir located in Kanchipuram district (formerly Chengalpattu), about $40 \mathrm{~km}$ west of Chennai (Daniels \& Rajagopal, 2004; Raghunathan, 1978). It is the largest reservoir that supplies drinking water to Chennai and has been a subject of study for the 
past 100 years with particular reference to its fish fauna. The earliest published source of information of the fish fauna of Chembarampakkam tank dates back to 1910 (Raj,1916) and has since been a source of interest to ichthyologists due to its diversity.

\section{Materials and methods}

The present study was carried out during a period of one year from April 2009 to March 2010 with field surveys conducted minimum twice a month. The major habitats mentioned in Daniels and Rajagopal (2004) were taken into consideration and a few additional habitats were identified and surveyed during the present study. The habitats are: 1) the large channels coming out of the dam shutters with dense vegetation both terrestrial and aquatic. 2) The small shallow channels without vegetation. 3) The stagnant shallow pools with clay substrate and aquatic vegetation. 4) The concrete lined channels with sandy substrate without vegetation and 5) the permanent deep waters of the reservoir.

Collection of fish samples was done using dip nets, dragnets and cast nets in the first four habitats. For the deep waters, fishes caught by the fishermen using gill nets and hook and line were recorded. The samples that were collected were identified using Daniels (2002), Jayaram (1999), and Talwar \& Jhingran (1991).

The checklist is updated primarily with data from the present study. Species which were not recorded in the present study, but reported in earlier published works have been included only after validation with the help of local fishermen who were shown photographs of the species.

\section{Results and Discussion}

The updated checklist includes 71 species of fish recorded from Chembarampakkam (Table: 1) of which 69 species were collected during this study. Of the 69 species, 36 have been recorded for the first time. Raj (1916), in his early study of the fishes of Madras (Chennai) in 1910-11 had mainly focused on the Adyar and Cooum rivers. He however mentions the large outlying tanks such as the Sembarambakkam (Chembarampakkam) in his work while discussing two species namely Chela cachius and Mystus cavasius. After Raj's pioneering study Raghunathan (1978) surveyed the lake over a period of ten months and listed 19 species of fish of which all but one namely Macrognathus aral, were recorded during the present study. The reason $M$. aral was not recorded in this study may be because of its burrowing habit, by which it may have eluded capture. However the presence of this fish in the lake is definite as it was recently collected from the lake by Eric Ramanujam (pers. com.).

The next work was done by Rema Devi et al. (1999) in which sampling was done on two separate days in the year 1995. Rema Devi et al. (1999) reported a total of 14 species, all of which were also recorded during the present study. More recently Daniels and Rajagopal (2004) updated the previous list based on their brief study that spanned just two days. They reported a total of 32 species of which 30 species were recorded in the present study. Of the two species not recorded during the present study Puntius amphibius has subsequently undergone major taxonomic revisions (Pethiyagoda \& Kottelat, 2005). As the fish earlier identified as $P$. amphibius is now shown to be $P$. mahecola, the fish recorded by Daniels and Rajagopal (2004) is uncertain. Due to lack of clarity, I retain the name $P$. amphibius in the checklist as it is still a valid species. However $P$. mahecola which is described in Pethiyagoda \& Kottelat (2005) was recorded in this survey. Nevertheless the other Puntius sp reported by Daniels and Rajagopal (2004) is excluded from the list.

Earlier taxonomic revisions have replaced $O$. melastigma with Oryzias dancena and O. carnaticus (Daniels, 2002; Parenti, 2008). Oryzias sp. reported in the other surveys is being treated as $O$. dancena as the male specimens collected during the present study had filamentous extensions of the anal fin (Daniels, 2002) and smaller adult size (Parenti, 2008).

Another two species which form a complex worth mentioning is Puntius fraseri and $P$. sharmai (Menon \& Rema Devi, 1992). Specimens collected in Chembarampakkam have overlapping characters of both the species. As Chennai is the type locality of $P$. sharmai, I identify the collected specimens as P. sharmai.

The present study has added eight non-native species namely, Oreochromis niloticus, Hemichromis bimaculatus, Ctenopharyngodon idellus, Cyprinus carpio, Hypophthalmichthys nobilis, Clarias gariepinus, Pterygoplichthys pardalis and Pterygoplichthys disjunctivus to the ones reported earlier; $O$. mossambicus, and Trichogaster trichopterus. O. niloticus, C. idellus, C. carpio, H. nobilis and C. gariepinus could have been introduced accidentally or intentionally through aquaculture and $H$. bimaculatus, $P$. pardalis 
and $P$. disjunctivus have certainly come in through the aquarium trade just as $T$. trichopterus.

It is interesting that some of the freshwater fish considered as North Indian Species are common in Chembarampakkam tank. Colisa lalia is an aquarium species that probably naturalized in the wetlands of Chennai as early as 1960 (Daniels \& Rajagopal, 2004). Lepidocephalichthys guntea may have colonized naturally due to river linking as it is not very popular in the aquarium trade. The occurrence of Badis badis (Knight \& Rema Devi, 2009) Puntius gelius (Knight, 2010) and Puntius orphoides, all North Indian species, is however puzzling. While Badis badis and Puntius gelius are both popularly traded in the European aquariums, I have not seen them in local aquariums. The claim that L. guntea displaced L. thermalis (Daniels \& Rajagopal, 2004, Daniels, 2006) needs to be further investigated as both species were collected in good numbers during the present study.

North Indian carps like Gibelion catla, Labeo rohita, Labeo calbasu and Cirrhinus cirrhosus are being stocked for fisheries purpose in the Chembarampakkam tank. Despite the presence of these and other non-native species it is remarkable that there are atleast 69 species belonging to 22 families in the Chembarampakkam tank. The high diversity may be attributed to the diversity of habitats sustained by the vast water spread. Premature claims of local extinction of fish species should be cautiously verified before any conservation measures are prescribed. This is precisely what the Wallacean Shortfall addresses.

\section{Acknowledgements}

I am thankful to Dr. K. Rema Devi (ZSI), Chennai for her help in the identification of the collected specimens. I thank my friend Chime Tsetan for his assistance in my field work. I also thank Mr. Venkat, Dolphin Aquarium, and Mr. G. Das, Care Earth, Chennai, for their help in the collection of the specimens.

\section{Literature Cited}

Daniels, R. J. R., 2002. Freshwater Fishes of Peninsular India. Universities Press, Hyderabad, India: 288.

Daniels, R. J. R. and B. Rajagopal, 2004. Fishes of Chembarampakkam Lake - A wetland in the outskirts of Chennai. Zoos' Print Journal, 19 (5): 1481-1483.
Daniels, R. J. R., 2006. Introduced fishes: a potential threat to the native freshwater fishes of Peninsular India. Journal of the Bombay Natural History Society, 103 (2\&3): 346-348.

Jayaram, K. C., 1999. The Freshwater Fishes of the Indian Region. Narendra Publishing House, New Delhi: 551.

Knight, J. D. M. and K. Rema Devi, 2009. On a record of Badis badis (Hamilton) (Teleostei: Perciformes: Badidae) from Tamil Nadu. Journal of Bombay Natural History Society, 106 (2): 329-330.

Knight, J. D. M., 2010. On a record of Puntius gelius (Hamilton, 1822) (Teleostei: Cypriniformes: Cyprinidae) from Tamil Nadu. Journal of Threatened Taxa, 2 (3): 786-787.

Kozlowski, G., 2008. Is the global conservation status assessment of a threatened taxon a utopia? Biodiversity and Conservation, 17 (3): 445-448.

Menon, A. G. K. \& K. Rema Devi, 1992. Puntius sharmai, a new cyprinid fish from Madras. Journal of the Bombay Natural History Society, 89 (3): 353-354.

Pethiyagoda, R. and M. Kottelat, 2005. The identity of the south Indian barb Puntius mahecola (Teleostei: Cyprinidae). Raffles Bulletin of Zoology Supplement, 12: $145-152$.

Parenti, L. R., 2008. A phylogenetic analysis and taxonomic revision of ricefishes, Oryzias and relatives (Beloniformes, Adrianichthyidae). Zoological Journal of the Linnean Society, 154: 494-610.

Raghunathan, M. B., 1978. Studies on seasonal tanks in Tamil Nadu. 1. Chembarampakkam tank. The Indian Journal of Zootomy, 19 (2): 81-85.

Raj, S. B., 1916. Notes on the freshwater fish of Madras. Records of the Indian Museum, XII (Part VI): 249-294.

Rema Devi, K., T. J. Indra, M. B. Raghunathan and M. Mary Bai, 1999. On a collection of fish fauna from Chennai; Chengleput and Tiruvallur Districts of Tamil Nadu. Records of the Zoological Survey of India, 97 (Part 4): 151-166.

Talwar, P. K. and A. G. Jhingran, 1991. Inland fishes of India and adjacent countries. Vol 1 \& 2. A.A. Balkema, Rotterdam: 541. 
Table 1: Checklist of Fish recorded from the Chembarampakkam tank for the past 100 years

\section{Family}

Notopteridae

Clupeidae

Cyprinidae
Cobitidae

Bagridae

Siluridae

Clariidae

Heteropneustidae Loricariidae

Adrianichthyidae Hemiramphidae

Belonidae

Aplocheilidae

Poecilidae

Mastacembelidae

\section{Scientific name}

Notopterus notopterus (Pallas)

Ehirava fluviatilis (Deraniyagala)

Amblypharyngodon microlepis (Bleeker)

Amblypharyngodon mola (Hamilton)

Chela cachius (Hamilton)

Cirrhinus cirrhosus (Bloch)

Ctenopharyngodon idellus (Cuvier \& Valenciennes)

Cyprinus carpio Linnaeus

Esomus barbatus (Jerdon)

Esomus danricus (Hamilton)

Esomus thermoicos (Hamilton)

Gibelion catla (Hamilton)

Rasboroides atukorali Deraniyagala

Hypophthalmichthys nobilis (Richardson)

Labeo calbasu (Hamilton)

Labeo rohita (Hamilton)

Laubuca laubuca (Hamilton)

Osteobrama cotio peninsularis (Silas)

Parluciosoma daniconius (Hamilton)

Puntius amphibius (Valenciennes)

Puntius chola (Hamilton)

Puntius conchonius (Hamilton)

Puntius dorsalis (Jerdon)

Puntius filamentosus (Valenciennes)

Puntius gelius (Hamilton)

Puntius mahecola (Valenciennes)

Puntius orphoides (Valenciennes)

Puntius sarana subnasutus (Valenciennes)

Puntius sharmai Menon \& Rema Devi

Puntius sophore (Hamilton)

Puntius ticto (Hamilton)

Puntius vittatus (Day)

Rasbora caverii (Jerdon)

Salmophasia clupeoides (Bloch)

Lepidocephalichthys guntea (Hamilton)

Lepidocephalichthys thermalis (Valenciennes)

Mystus bleekeri (Day)

Mystus cavasius (Hamilton)

Mystus keletius (Valenciennes)

Mystus vittatus (Bloch)

Neotropius atherinoides (Bloch)

Wallago attu (Bloch \& Schneider)

Clarias gariepinus (Burchell)

Heteropneustes fossilis (Bloch)

Pterygoplichthys disjunctivus (Weber)

Pterygoplichthys pardalis (Castelnau)

Oryzias dancena (Hamilton)

Hyporhamphus limbatus (Valenciennes)

Xenentodon cancila (Hamilton)

Aplocheilus parvus (Sundara Raj)

Gambusia affinis (Baird \& Girard)

Macrognathus aral (Bloch \& Schneider)

Macrognathus pancalus Hamilton

Mastacembelus armatus (Lacepede)

\section{Year of record}

2004, 2010

2010

1999, $2004 \& 2010$

2010

1916, 2010

2010

2010

2010

2010

1978, 1999, 2004 \& 2010

2010

2010

2010

2010

2010

2010

2004, 2010

2010

1978, 1999, 2004 \& 2010

2004

1978, 1999, 2004 \& 2010

1978, 2004 \& 2010

1978, 1999, 2004 \& 2010

$2004 \& 2010$

2010

2010

2010

$2004 \& 2010$

2010

1978, 1999, 2004 \& 2010

1978, 1999, $2004 \& 2010$

$2004 \& 2010$

2004 \& 2010

1978, 1999, 2004 \& 2010

$2004 \& 2010$

1978 \& 2010

2010

1916, 2004 \& 2010

2004, 2010

1978, 1999, 2004 \& 2010

$2004 \& 2010$

2010

2010

2010

2010

2010

1999, $2004 \& 2010$

2010

$2004 \& 2010$

2010

1978 \& 2010

1978

1978, 1999, 2004 \& 2010

2010 


$\begin{array}{lll}\text { Chandidae } & \text { Chanda nama Hamilton } & 2010 \\ & \text { Parambassis lala (Hamilton) } & 2010 \\ & \text { Parambassis ranga (Hamilton) } & 1978,2004 \text { \& } 2010 \\ \text { Nandidae } & \text { Pseudambassis baculis (Hamilton) } & 2010 \\ \text { Cichlidae } & \text { Badis badis (Hamilton) } & 2010 \\ & \text { Etroplus maculatus (Bloch) } & 1978,1999,2004 \text { \& } 2010 \\ & \text { Hemichromis bimaculatus Gill } & 2010 \\ \text { Gobiidae } & \text { Oreochromis mossambicus (Peters) } & 1978,1999,2004 \& 2010 \\ \text { Anabantidae } & \text { Oreochromis niloticus (Linnaeus) } & 2010 \\ \text { Belontiidae } & \text { Glossogobius giuris (Hamilton) } & 1978,2004 \& 2010 \\ & \text { Anabas testudineus (Bloch) } & 2010 \\ \text { Channidae } & \text { Colissa lalia (Hamilton) } & 1978,1999,2004 \& 2010 \\ & \text { Pseudosphromenus cupanus (Cuvier) } & 2010 \\ & \text { Trichogaster trichopterus (Pallas) } & 2004 \& 2010 \\ & \text { Channa gachua (Hamilton) } & 2010 \\ & \text { Channa punctatus (Bloch) } & 1978,2004 \& 2010\end{array}$

Note- 1916 - Raj; 1978 - Raghunathan; 1999 - Rema Devi et al.; 2004 - Daniels \& Rajagopal; 2010 - Present study. 


\section{PLATE 01}

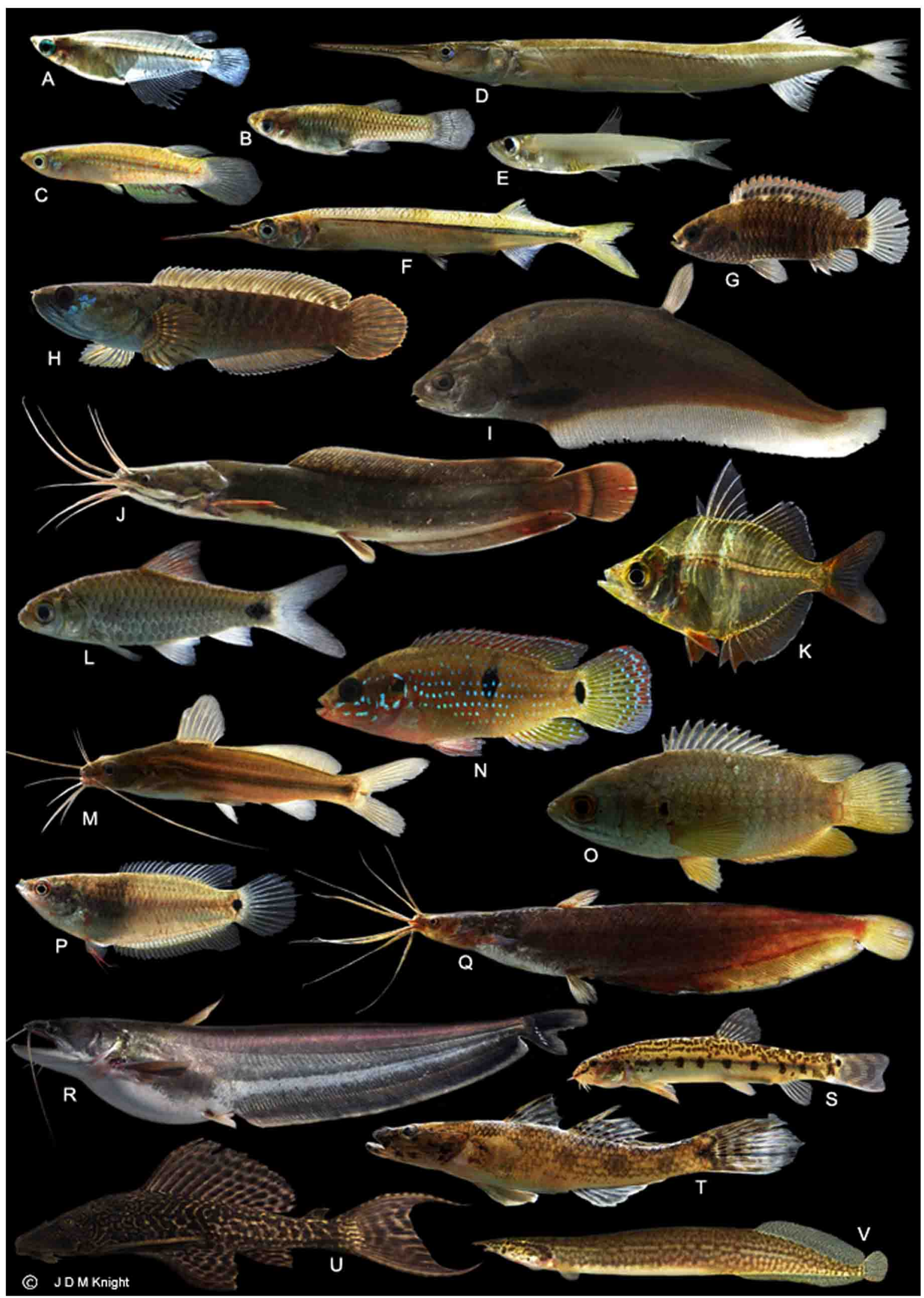

Fig. 1: Various families of Fish collected from Chembarampakkam tank; A- Adrianichthyidae Oryzias dancena (25 mm); B- Poecilidae Gambusia affinis $(30 \mathrm{~mm})$; C- Aplocheilidae Aplocheilus parvus $(25 \mathrm{~mm})$; D- Belonidae Xenentodon cancila (250 mm); E- Clupeidae Ehirava fluviatilis (40 mm); F- Hemiramphidae Hyporhamphus limbatus (150 mm); G- Nandidae Badis badis $(25 \mathrm{~mm})$; H- Channidae Channa gachua $(100 \mathrm{~mm})$; I- Notopteridae Notopterus notopterus $(220 \mathrm{~mm})$; J- Clariidae Clarias gariepinus (490 mm); K- Chandidae Parambassis lala (30 mm); L- Cyprinidae Puntius mahecola $(41 \mathrm{~mm})$; M- Bagridae Mystus bleekeri (95 mm); N-Cichlidae Hemichromis bimaculatus $(60 \mathrm{~mm})$; O- Anabantidae Anabas testudineus $(90 \mathrm{~mm})$; P- Belontiidae Pseudosphromenus cupanus (30 mm); Q- Heteropn-eustidae Heteropneustes fossilis $(250 \mathrm{~mm}) ; \mathbf{R}$-Siluridae Wallago attu $(800 \mathrm{~mm}) ;$ S- Cobitidae Lepidocephalus thermalis (55 mm); TGobiidae Glossogobius giuris (200 mm); U- Loricariidae Pterygoplichthys disjunctivus (245 mm); V- Mastacembelidae Macrognathus pancalus $(150 \mathrm{~mm})$. 